\title{
ORALLY ACTIVE OESTROGENS AND PROGESTINS IN PREVENTION OF PREGNANCY IN RATS
}

\author{
U. K. BANIK, G. REVESZ AND F. HERR \\ Ayerst Laboratories, Montreal, Canada \\ (Received 20th May 1968, revised 17th September 1968)
}

\begin{abstract}
Summary. Orally active synthetic oestrogens and progestins were studied in tests to prevent pregnancy in rats. By daily administration the contraceptive effect of ethynyloestradiol and a new oestrogen, 17 $\alpha$-[3-furyl]-estra-1,3,5(10),7-tetraene-3,17-diol 3-acetate (AY-11483), was potentiated by three progestins, namely, chlormadinone acetate, 6-chloro-3 $\beta, 17 \alpha$-dihydroxypregn-4,6-dien-20-one diacetate (AY-11440) and medrogestone. AY-11483 given alone, or together with AY-11440, was more potent in preventing ovulation and implantation than ethynyloestradiol alone or in combination with other compounds. Chlormadinone acetate or AY-11440 alone were completely inactive in all the assays. The mode of action of oestrogen or oestrogen and progestin in the prevention of ovulation and implantation is discussed. In the rat, implantation seems more vulnerable to oestrogens than does ovulation.
\end{abstract}

\section{INTRODUCTION}

Recently, Diczfalusy (1968) reviewed the use of various oestrogens and progestins and their possible mode of action in blocking pregnancy both in humans and laboratory animals. The present paper reports experiments on the prevention of pregnancy in rats in which a series of tests was used to study a new oestrogen, AY-11483, and to compare its effects with other known oestrogens and progestins. The chemical and biological properties of AY-11483 were reported earlier (Lefebvre, Marshall, Revesz, Banik \& Deghenghi, 1967).

\section{MATERIALS AND METHODS}

All experiments were performed on cyclic adult (180 to $250 \mathrm{~g}$ ) Sprague-Dawley rats. Standard (Purina) diet and water were given unrationed and animals were kept in uniform conditions with exposure to $12 \mathrm{hr}$ light and $12 \mathrm{hr}$ dark. All compounds were dissolved or suspended in sesame oil and administered orally by stomach tube. Doses are expressed as the weight of compounds administered to each rat. Unless otherwise stated, treatments were started on the day of pro-oestrus of the normal cycle. Day 1 of pregnancy was designated as the day when either a vaginal plug or spermatozoa were found after placing overnight with males known to be fertile. Statistical analysis of the data from 
rats with ova or implantations was made using the four-fold contingency test tables of Mainland \& Murray (1952); the average number of ova or implantation sites in each rat in the experimental series was compared with those of the controls by using Student's $t$ test. The structural formulae of different oestrogens and progestins used in these studies are presented in Text-fig. 1.

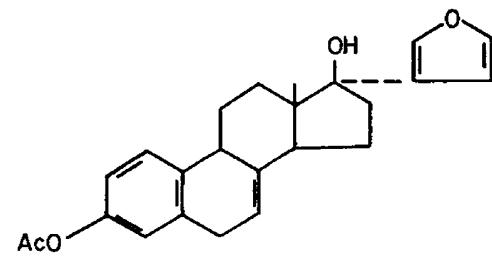

AY- 11483

$17 a-(3-$ furyl) - estra $-1,3,5(10), 7-$

tetraene-3,17- dioi 3 -acetate

(Lefebvre ef al., 1967)<smiles>C#CCC1(O)CCC2C3CCc4cc(OC)ccc4C3CCC21</smiles>

Mestronol<smiles>CC(=O)OC1(C(C)=O)CCC2C3CC(Cl)[C@@]45CCC(=O)C[C@]4(CCC35)C2CC1</smiles>

Chlormadinone acetate<smiles>C#CC1(O)CCC2C3CCc4cc(O)ccc4C3CCC21</smiles>

Ethynyloestrodiol<smiles>CC(=O)OC1CCC23CC(OC(C)=O)CCC45CCCC4(C(C)=O)CCC5C2C=C(Cl)C3C1</smiles>

AY -11440

6 -chloro- $3 \beta, 17 \alpha-$ dihydroxy pregn4,6-dien-20-one diacetate (Revesz et al.,1967)

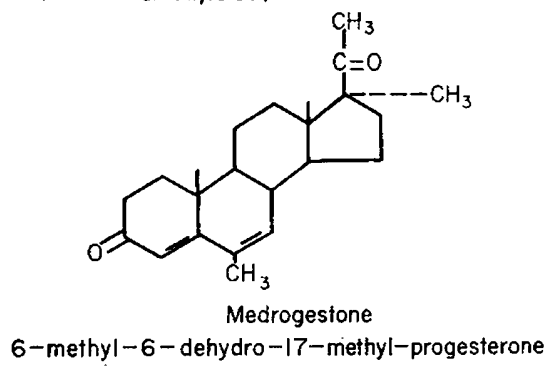

TEXT-FIG. 1. Structural formulae of oestrogens and progestins used in prevention of pregnancy in rats.

\section{Daily administration of oestrogens and progestins}

Groups of ten female rats were given the test compound every day for 35 days during cohabitation with males. Two males were put in each cage containing five females which were checked every morning for evidence of mating. Mated animals were killed on Day 9 or 10 of pregnancy and the number of implantations counted. All other animals were killed 10 days after the cohabitation period of 35 days and uteri examined for implantation sites.

Anti-ovulatory effect of oestrogens and progestins given alone or in different combinations

The test compound was administered to 4-day cyclic rats, either 1 day before pro-oestrus or on each day starting on the morning of oestrus until the next 
pro-oestrus. The vaginal cytology was studied every morning between 09.00 and 10.00 hours. Treated and control animals were killed on the day of postoestrous after treatment. The oviduct and uterus were examined for the presence of ova.

Anti-implantation effect of oestrogens and progestins given alone or in different combinations

In these experiments, all compounds were tested, in rats after mating, by the method of Banik \& Pincus (1962). As before, different oestrogens were given alone or in combination with a progestin on Day 1, or on Days 1 to 5 of pregnancy. All animals were killed on Day 9 or 10 of pregnancy and the number of implantations was counted.

\section{RESULTS}

Daily administration of oestrogens and progestins

Results shown in Table 1 reveal that none of the oestrogens alone (10 $\mu \mathrm{g} / \mathrm{rat}$, Groups 2, 3 and 4) and none of the progestins alone (100 $\mu \mathrm{g} / \mathrm{rat}$, Groups 5,6 and 7 ) were completely effective in preventing pregnancy when given over a period of 35 days. A marginally significant reduction of implantations was

TABLE 1

DAILY ORAL ADMINISTRATION OF OESTROGENS AND PROGESTINS IN PREVENTION OF PREGNANGY*

\begin{tabular}{|c|c|c|c|c|}
\hline Group & $\begin{array}{c}\text { Oestrogen } \\
(10 \mu \mathrm{g} / \mathrm{rat})\end{array}$ & $\begin{array}{c}\text { Progestin } \\
(100 \mu \mathrm{g} / \text { rat })\end{array}$ & $\begin{array}{c}\text { No. of rats } \\
\text { pregnant }\end{array}$ & $\begin{array}{l}\text { Implantations } \\
\text { (mean } \pm \text { S.E. })\end{array}$ \\
\hline $\begin{array}{r}1 \\
2 \\
3 \\
4 \\
5 \\
6 \\
7 \\
8 \\
9 \\
10 \\
11 \\
12\end{array}$ & \begin{tabular}{l} 
Oil control \\
Ethynyloestradiol \\
AY-11483 \\
Mestranol \\
\multicolumn{1}{c}{-} \\
Ethynyloestradiol \\
Mestranol \\
AY-11483 \\
AY-11483 \\
AY-11483
\end{tabular} & $\begin{array}{l}\text { Oil control } \\
\text { ב- } \\
\text { Chlormadinone acetate } \\
\text { AY-11440 } \\
\text { Medrogestone } \\
\text { Chlormadinone acetate } \\
\text { Chlormadinone acetate } \\
\text { AY-11440 } \\
\text { Medrogestone } \\
\text { Chlormadinone acetate }\end{array}$ & $\begin{array}{c}9 / 10 \\
7 / 10 \\
6 / 10 \\
8 / 10 \\
9 / 10 \\
10 / 10 \\
8 / 10 \\
0 / 10 \dagger \\
8 / 10 \\
0 / 10 \dagger \\
0 / 10 \dagger \\
0 / 12 \dagger\end{array}$ & $\begin{array}{l}10 \cdot 7 \pm 0.55 \\
7 \cdot 4 \pm 1 \cdot 65 \\
6 \cdot 5 \pm 0.99 \dagger \\
9 \cdot 5 \pm 0.60 \\
12 \cdot 3 \pm 0 \cdot 73 \\
10 \cdot 1 \pm 1 \cdot 26 \\
9 \cdot 6 \pm 0 \cdot 24 \\
0 \dagger \\
9 \cdot 7 \pm 0.86 \\
0 \dagger \\
0 \dagger \\
0 \dagger\end{array}$ \\
\hline
\end{tabular}

* Treatment was continued daily for 35 days.

$\dagger$ Significantly different from control, $P<0 \cdot 01$.

found only in the group treated with AY-11483. However, combinations of ethynyloestradiol and chlormadinone acetate, AY-11483 and AY-11440, AY-11483 and medrogestone, and AY-11483 and chlormadinone acetate were all significantly effective in preventing pregnancy (Groups 8, 10,11 and 12). However, neither the oestrous cycle nor the mating behaviour of these animals was disturbed. The mestranol-chlormadinone acetate combination was inactive in this test (Group 9).

Anti-ovulatory effect of oestrogens and progestins given alone or in different combinations

All ova were collected from the oviduct and none was found in the uterus. The data in Table 2 show that neither ethynyloestradiol nor AY-11483 (10 or 
$100 \mu \mathrm{g} / \mathrm{rat}$, Groups 2 to 5) given 1 day before pro-oestrus, was effective in preventing ovulation. These oestrogens were only effective if given at the $100 \mu \mathrm{g}$ dose level over the entire cycle (Table 3); at the $10 \mu \mathrm{g}$ dose level AY-11483 was significantly more potent than ethynyloestradiol. Neither chlormadinone acetate nor AY-11440 given either 1 day before pro-oestrus (Table 2) or during

TABLE 2

ANTI-OVULATORY EFFEGT OF OESTROGENS AND PROGESTINS GIVEN ALONE OR IN DIFFERENT GOMBINATIONS*

\begin{tabular}{|c|c|c|c|c|}
\hline Group & $\begin{array}{l}\text { Oestrogen } \\
(\mu \mathrm{g} / \mathrm{rat})\end{array}$ & $\begin{array}{c}\text { Progestin } \\
(100 \mu g / \text { rat })\end{array}$ & $\begin{array}{l}\text { No. of } \\
\text { rats that } \\
\text { ovulated }\end{array}$ & $\begin{array}{c}\text { No. of ova } \\
(\text { mean } \pm \text { S.E. })\end{array}$ \\
\hline $\begin{array}{r}1 \\
2 \\
3 \\
4 \\
5 \\
6 \\
7 \\
8 \\
9 \\
10 \\
11\end{array}$ & $\begin{array}{l}\text { Oil control } \\
\text { Ethynyloestradiol }(10) \\
\text { Ethynyloestradiol (100) } \\
\text { AY-11483 (10) } \\
\text { AY-11483 (100) } \\
\quad- \\
\text { Ethynyloestradiol (10) } \\
\text { AY-11483 (10) } \\
\text { Ethynyloestradiol (10) } \\
\text { AY-11483(10) }\end{array}$ & $\begin{array}{l}\text { Oil control } \\
= \\
\text { Chlormadinone acetate } \\
\text { AY-11440 } \\
\text { Chlormadinone acetate } \\
\text { Chlormadinone acetate } \\
\text { AY-11440 } \\
\text { AY-11440 }\end{array}$ & $\begin{array}{l}13 / 13 \\
6 / 6 \\
10 / 12 \\
5 / 6 \\
11 / 11 \\
6 / 6 \\
6 / 6 \\
5 / 5 \\
6 / 6 \\
5 / 6 \\
5 / 6\end{array}$ & $\begin{array}{l}11 \cdot 7 \pm 0.60 \\
10 \cdot 5 \pm 1 \cdot 21 \\
11.9 \pm 1 \cdot 4 \\
10 \cdot 7 \pm 0.94 \\
11 \cdot 7 \pm 0.34 \\
11 \cdot 0 \pm 0.48 \\
10.5 \pm 0.89 \\
8 \cdot 6 \pm 1.44 \dagger \\
9 \cdot 1 \pm 1 \cdot 11 \\
10 \cdot 2 \pm 1.50 \\
10.2 \pm 0.50\end{array}$ \\
\hline
\end{tabular}

* Treatment given 1 day before pro-oestrus.

$\dagger$ Significantly different from control, $P<0.05$.

TABLE 3

ANTI-OVULATORY EFFECT OF OESTROGENS AND PROGESTINS GIVEN ALONE OR IN DIFFERENT COMBINATIONS*

\begin{tabular}{|c|c|c|c|c|}
\hline Group & $\begin{array}{l}\text { Oestrogen } \\
(\mu g / \text { rat })\end{array}$ & $\begin{array}{c}\text { Progestin } \\
(100 \mu g / \text { rat })\end{array}$ & $\begin{array}{l}\text { No. of } \\
\text { rats that } \\
\text { ovulated }\end{array}$ & $\begin{array}{c}\text { No. of ova } \\
\text { (mean } \pm \text { S.E. })\end{array}$ \\
\hline $\begin{array}{r}1 \\
2 \\
3 \\
4 \\
5 \\
6 \\
7 \\
8 \\
9 \\
10 \\
11\end{array}$ & $\begin{array}{l}\text { Oil control } \\
\text { Ethynyloestradiol (10) } \\
\text { Ethyyloestradiol (100) } \\
\text { AY-11483 (10) } \\
\text { AY-11483 (100) } \\
\text { Ethynyloestradiol (10) } \\
\text { AY-11483 (10) } \\
\text { Ethynyloestradiol (10) } \\
\text { AY-11483 (10) }\end{array}$ & $\begin{array}{l}\text { Oil control } \\
\qquad- \\
- \\
\text { Chlormadinone acetate } \\
\text { AY-11440 } \\
\text { Chlormadinone acetate } \\
\text { Chlormadinone acetate } \\
\text { AY-11440 } \\
\text { AY-11440 }\end{array}$ & $\begin{array}{l}13 / 13 \\
6 / 8 \\
2 / 7 \dagger \\
2 / 8 \dagger \\
0 / 7 \ddagger \\
9 / 10 \\
10 / 10 \\
8 / 14 \\
10 / 20 \\
9 / 13 \\
5 / 20 \ddagger\end{array}$ & $\begin{array}{l}11.7 \pm 0.60 \\
10.1 \pm 0.40 \\
11 \cdot 0 \pm 0.0 \\
13.5 \pm 0.50 \\
0.0 \ddagger \\
10.7 \pm 0.83 \\
10 \cdot 1 \pm 0.95 \\
6.5 \pm 0.68 \ddagger \\
10.0 \pm 1.04 \\
10.4 \pm 0.91 \\
9.2 \pm 1.11 \dagger\end{array}$ \\
\hline
\end{tabular}

* Treatment given once daily from one post-oestrus to the next pro-oestrus; not more than 4 days.

+ Significantly different from control, $P<0 \cdot 05$.

$\$$ Significantly different from control, $P<0.01$.

the whole of the cycle (Table 3) prevented ovulation. Furthermore, $10 \mu \mathrm{g}$ of either of these oestrogens plus $100 \mu \mathrm{g}$ of either of these progestins, when given in a single dose 1 day before pro-oestrus, was found inactive (Table 2). Partial inhibition of ovulation was achieved with the oestrogen-progestin combinations 
given over the entire length of the cycle (Table 3 ). Of these treatments, it seems that $10 \mu \mathrm{g}$ of AY-11483 alone or in combination with $100 \mu \mathrm{g}$ of AY-11440 (Table 3) was the most potent in this test.

\section{Anti-implantation effect of different oestrogens given alone or in combination with a progestin}

The results presented in Table 4 show that $10 \mu \mathrm{g}$ of either ethynyloestradiol or AY-11483 is partially effective in preventing the implantation of ova in mated rats when administered over a period of 5 days (Groups 2 and 4). These two oestrogens were more effective if given in doses of $100 \mu \mathrm{g}$ on Day 1

TABLE 4

ANTI-IMPLANTATION EFFECT OF DIFFERENT OESTROGENS GIVEN ALONE OR IN COMBINATION WITH A PROGESTIN*

\begin{tabular}{|c|c|c|c|c|c|}
\hline Group & 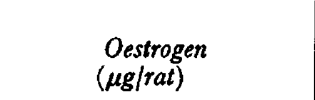 & $\begin{array}{l}\text { Progestin } \\
(\mathrm{mg} / \text { rat })\end{array}$ & $\begin{array}{c}\text { Days of } \\
\text { treatment } \\
\text { after mating }\end{array}$ & $\begin{array}{c}\text { No. of } \\
\text { rats with } \\
\text { implantations }\end{array}$ & $\begin{array}{l}\text { Implantations } \\
\text { (mean土S.E.) }\end{array}$ \\
\hline $\begin{array}{l}1 \\
2 \\
3 \\
4 \\
5 \\
6 \\
7\end{array}$ & $\begin{array}{l}\text { Oil control } \\
\text { Ethynyloestradiol (10) } \\
\text { Ethynyloestradiol (100) } \\
\text { AY-11483 (10) } \\
\text { AY-11483 (100) } \\
\text { Mestranol (100) }\end{array}$ & $\begin{array}{c}\text { Oil control } \\
= \\
= \\
= \\
\text { Chlormadinone acetate }\end{array}$ & $\begin{array}{l}1 \text { to } 5 \\
1 \text { to } 5 \\
1 \\
1 \text { to } 5 \\
1 \\
1 \\
1 \text { to } 5\end{array}$ & $\begin{array}{l}11 / 12 \\
7 / 9 \\
2 / 10 \ddagger \\
4 / 9 \ddagger \\
0 / 6 \ddagger \\
7 / 11 \\
8 / 9\end{array}$ & $\begin{array}{c}12.2 \pm 0.65 \\
7.4 \pm 1.64 \dagger \\
11.0 \pm 0 \\
7.0 \pm 1.22 \pm \\
0.0 \pm 0.0 \pm \\
9.4 \pm 1.41 \\
9.7 \pm 0.58 \dagger\end{array}$ \\
\hline 8 & - & $\begin{array}{l}(0 \cdot 1) \\
\text { Chlormadinone acetate } \\
(2 \cdot 5)\end{array}$ & 1 & $5 / 6$ & $12 \cdot 3 \pm 0 \cdot 62$ \\
\hline $\begin{array}{r}9 \\
10\end{array}$ & - & $\begin{array}{l}\text { AY-11440 (0.1) } \\
\text { AY-11440 (2.5) }\end{array}$ & 1 to 5 & $\begin{array}{l}6 / 9 \\
5 / 5\end{array}$ & $\begin{array}{l}13 \cdot 1 \pm 0.87 \\
13.2 \pm 0.48\end{array}$ \\
\hline 11 & Ethynyloestradiol (10) & $\begin{array}{l}\text { Chlormadinone acetate } \\
(0 \cdot 1)\end{array}$ & I to 5 & $5 / 5$ & $11.0 \pm 0.31$ \\
\hline 12 & AY-11483 (10) & $\begin{array}{l}\text { Chlormadinone acetate } \\
(0 \cdot 1)\end{array}$ & 1 to 5 & $3 / 9 \ddagger$ & $3 \cdot 6 \pm 1 \cdot 20 \ddagger$ \\
\hline $\begin{array}{l}13 \\
14\end{array}$ & $\begin{array}{l}\text { Ethynyloestradiol (10) } \\
\text { AY-11483 (10) }\end{array}$ & $\begin{array}{l}\text { AY-11440 (0.1) } \\
\text { AY-11440 (0.1) }\end{array}$ & $\begin{array}{l}1 \text { to } 5 \\
1 \text { to } 5\end{array}$ & $\begin{array}{l}4 / 8 \\
0 / 6 \ddagger\end{array}$ & $\begin{array}{l}9 \cdot 2 \pm 0 \cdot 75 \dagger \\
0 \ddagger\end{array}$ \\
\hline
\end{tabular}

* Treatment given orally in mated rats during the pre-implantation period.

$\dagger$ Significantly different from control, $P<0.05$.

$\ddagger$ Significantly different from control, $P<0.01$.

of pregnancy (Groups 3 and 5). Mestranol $(100 \mu \mathrm{g}$ ) given on Day 1 of pregnancy (Group 6) was not significantly effective in the inhibition of implantation. AY-11483 was more potent than ethynyloestradiol or mestranol in this test. When ethynyloestradiol $(10 \mu \mathrm{g})$ was given in combination with chlormadinone acetate $(100 \mu \mathrm{g})$ for 5 days, implantation was not inhibited (Group 11); however, corresponding doses of AY-11483 and chlormadinone acetate gave a significant inhibition of implantation (Group 12). When ethynyloestradiol $(10 \mu \mathrm{g})$ was given with AY-11440 $(100 \mu \mathrm{g})$, only a partial inhibition of implantation was achieved (Group 13), but treatment with the same quantity of AY-11483 together with AY-11440 resulted in the complete inhibition of implantation (Group 14). In a subsequent study, we failed to collect ova on Day 5 of pregnancy from the reproductive tract of rats treated daily with AY-11483 $(10 \mu \mathrm{g})$ and AY-11440 $(100 \mu \mathrm{g})$ during the preceding 4 days. 
Chlormadinone acetate or AY-11440 given in doses up to $2.5 \mathrm{mg}$ was inactive in preventing implantation (Groups 7 to 10 ).

\section{DISGUSSION}

The results presented in this paper demonstrate the anti-fertility effect of a new orally active oestrogen AY-11483 given alone in moderately high doses or in combination with a progestin in lower doses. The new oestrogen was more effective than various other oestrogens given in similar doses (Tables 3 and 4). It is pertinent to point out here that we have found AY-11483 to be more active than mestranol or ethynyloestradiol as percentage of the median cornifying dose in rats (Revesz, Banik \& Herr, unpublished observations). The effect, in preventing pregnancy, of continuous treatment over 35 days with AY-11483 or ethynyloestradiol (Table 1) was potentiated by AY-11440 and chlormadinone acetate, perhaps by interfering with both ovulation and implantation. It was also noted that the anti-implantation effect of AY-11483 was potentiated more by AY-11440 than by chlormadinone acetate (Table 4), although the progestational activity of these two progestins in rabbits is similar (Revesz, Banik \& Herr, 1967). Synergism in anti-ovulatory tests between ethynyloestradiol and chlormadinone acetate in rabbits (Chambon \& Veve, 1966) and between ethynyloestradiol and norgestrel in rats (Edgren, Jones \& Peterson, 1967) has been reported before and was confirmed in these experiments.

Data obtained from the anti-ovulatory assay (Tables 2 and 3) revealed that a prolonged treatment with oestrogen was more effective in preventing ovulation than the single dose. Oestrogens could conceivably inhibit the release of both FSH and LH (Dorfman \& Dorfman, 1963; McCann \& Taleisnik, 1961) and thus prevent ovulation. The other possibility is that oestrogens maintain the life of the corpus luteum. Thus, the progesterone produced by the corpora lutea may act independently, or together with the oestrogen to inhibit the release of LH and block ovulation (Watnick, Gibson, Vinegra \& Tolksdorf, 1964). However, in a subsequent experiment (Tables 2 and 3), a 'breakthrough' in ovulation was observed in some rats when $10 \mu \mathrm{g}$ of ethynyloestradiol or AY-11483 was given daily during the pre-ovulatory period in combination with $100 \mu \mathrm{g}$ of chlormadinone acetate or AY-11440. Similar effects with oral contraceptives were suggested in human trials (Rudel, Martinez-Manautou \& Maquco-Topete, 1965). Since a single administration of $100 \mu \mathrm{g}$ of either ethynyloestradiol or AY-11483 did not prevent ovulation (Table 2), but precluded implantation (Table 4), it is believed that the process of implantation in rats is more vulnerable to these oestrogens than is ovulation.

The primary contraceptive effect of excessive oestrogen or oestrogen plus progestin in mated rats before nidation was perhaps due to the expulsion of fertilized eggs (Banik \& Pincus, 1964; Pincus, Banik \& Jacques, 1964; Bennett, Kendle, Vallance \& Vickery, 1966). Although a potent anti-oestrogenic progestin, on the other hand, delays the implantation of eggs (Nutting \& Sollman, 1967), data presented in this paper (Table 4) are in agreement with our previous findings (Revesz et al., 1967) that both chlormadinone acetate and 
AY-11440 alone do not inhibit implantation or cause delayed implantation in rats. It may also be pertinent that oestrogen or oestrogen plus progestin may create an unfavourable uterine environment and preclude implantation. Although the perfect functional equilibrium between oestrogen and progesterone is required for ovum implantation (Psychoyos, 1966; Mayer, 1966), the expulsion of eggs by AY-11483 alone or with AY-11440 (Table 4) is thought to be the primary mode of action.

The present study indicates that AY-11483 is orally active in preventing pregnancy in rats by interfering with both ovulation and implantation.

\section{ACKNOWLEDGMENTS}

We are grateful to Dr R. I. Dorfman of Syntex Research Laboratories for a gift of chlormadinone acetate. Our sincere thanks are due to Mrs Irene Haltrecht and to Mrs Monique Politick for their efficient technical assistance.

\section{REFERENCES}

Banik, U. K. \& Pincus, G. (1962) The effect of steroidal anti-progestins on the implantation of fertilized eggs of rats and mice. Proc. Soc. exp. Biol. Med. 111, 595.

Banik, U. K. \& Pincus, G. (1964) Estrogen and transport of ova in the rat. Proc. Soc. exp. Biol. Med. 116, 1032.

Bennett, J. P., Kendle, K. E., Vallance, D. K. \& Vickery, B. H. (1966) A comparison of the antifertility and hormonal activities of some new synthetic oestrogens. Acta endocr., Copenh. 53, 443.

Chambon, Y. \& Veve, Y. (1966) Effects anti-ovulatoires de l'ethynyl oestradiol et du mestranol, isolement ou en association avec le chlormadinone, chez le lapin et chez le rat. C. r. Séanc. Soc. Biol. 160, 2411.

Diczfalusy, E. (1968) Mode of action of contraceptive drugs. Am. F. Obstet. Gynec. 100, 136.

Dorfman, R. I. \& Dorfman, A. S. (1963) Pituitary gonadotropic inhibitory action of estrone in parabiotic rats. Endocrinology, 72, 115.

Edgren, R., Jones, R. C. \& Peterson, D. L. (1967) A biological classification of progestational agents. Fert. Steril. 18, 238.

Lefebvre, Y., Marshald, D. J., Revesz, C., Banik, U. K. \& Deghenghi, R. (1967) Preparation and biological properties of 17 -substituted oestradiol derivatives in the 8-normal and 8-iso series. Am. Chem. Soc. Meet. Abstract No. 154, p. 10.

Mainland, D. \& Murray, I. M. (1952) Tables for use in four-fold contingency tests. Science, N.r. 116, 591 .

MAYER, G. (1966) Techniques de nidation retardée chez la ratte et possibilités d'utilisation en tératogénèse experimentale. Bull. schweiz. Akad. med. Wiss. 22, 123.

McCann, S. M. \& TALEISNiK, S. (1961) The effect of estrogen on plasma luteinizing hormone (LH) activity in the rats. Endocrinology, 69, 909.

Nutring, E. T. \& Sollman, P. B. (1967) Delay of implantation in intact rats treated with progestins. Acta endocr., Copenh. 54, 8.

Pincus, G., Banik, U. K. \& JAcQues, J. (1964) Further studies on implantation inhibitors. Steroids, 4, 657.

Psychoyos, A. (1966) Recent researches on egg implantation. Ciba Fdn Study Grps, 23, 4.

ReVesz, G., BANIK, U. K. \& HeRR, F. (1967) Hormonal and biological activities of $3 \beta, 17 \alpha$-diacetoxy-6chloropregna-4,6-diene-20-one (AY-11,440). Steroids, 10, 291,

Rudel, H. W., Martinez-Manautou, J. \& Maquco-Topete, M. (1965) The role of progestogens in the hormonal control of fertility. Fert. Steril. 16, 158.

Watnick, A. S., Grbson, J., Vinegra, M. \& Tolksdorf, S. (1964) Ethynyl estradiol: A potent orally active contraceptive in rats. Proc. Soc. exp. Biol. Med. 116, 343. 